Redigeret af

Mads Peter Karlsen og Kaspar Villadsen: Sundhed og Magt - Perspektiver på biopolitik og ledelsesteknologi

Hans Reitzels Forlag, 2017.

Sundhedspolitikken er et af den danske velfærdsstats definerende politikområder. Det er denne politik, der skal sørge for at danskerne har et langt og godt liv, at sygdom kureres hurtigt og effektivt, og ikke mindst at vi kan leve et produktivt liv, der kan komme den enkelte og samfundsøkonomien til gode. Omkring en tiendedel af bruttonationalproduktet allokeres til dette politikområde, som med god grund har en stor bevågenhed fra politikere, offentlige ledere og den bredere offentlighed.

På denne baggrund er der et stort behov for forskellige typer af samfundsvidenskabelig forskning i sundhedspolitikken. I Danmark findes der allerede en ganske omfattende samfundsvidenskabelig forskning. Imidlertid har en stor del af denne forskning, især den sundhedsøkonomiske, karakter af at være anvendelsesorienteret, dvs. den søger at analyse sundhedspolitikken mhp. at gøre vores politikere bedre i stand til at få mest mulig værdi for de mange offentlige kroner, der tilføres området. Det er selvfølgelig vigtigt med anvendelsesorienteret forskning, men som Sundhed og Magt pointerer, så er der også behov for forskning, der kritisk belyser de forskellige former form magt, der indgår i moderne sundhedspolitik. Antologien har således en berettigelse, men som det vil fremgå af det følgende skæmmes den af uklare målsætninger og målgruppeidentifikation samt af manglende forsøg på at give et overblik over den eksisterende litteratur og kritiske teorier på området.

Lad os starte med det positive. Antologien byder på ni kapitler, som alle er velskrevne, de fleste indsigtsfulde og nogle også ganske originale. Her skal det selvfølgelig nævnes, at en del af kapitlerne er en direkte oversættelse af artikler/kapitler, som har været udgivet tidligere. Mange af kapitlerne er mere eller mindre direkte inspireret af Michel Foucault's magt-videnanalytik samt hans begreber biopolitik og (liberal) styringsrationalitet (governementalitet). Vi finder dog også kapitler, der anvender Niklas Luhmans, Slavoj Zizeks og Bruno Latours teorier og begrebsapparater.

Især fire kapitler fortjener rosende omtale, idet de alle belyser samspillet mellem magt og forskellige former for frihed og modstand på en original, analytisk stringent og ganske nuanceret facon. Thomas Lemkes Sundhed og sygdom $i$ den postgenomiske æra (kapitel 1.) fremfører en indsigtsfuld og nuanceret diskussion 
af de farer og gevinster ved den stigende brug af prædiktive gentest. På den ene side giver denne teknologi, hvis omkostninger er stadigt faldende, myndigheder og virksomheder mulighed for at overvåge og regulere borgeres adfærd på nye måder. For eksempel kan forsikringsselskaber anvende oplysningerne til at diskriminere deres kunder på nye måder, og myndighederne kan gå endnu længere i deres forsøg på at pushe livsstilsændringer hos borgerne. På den anden side afviser Lemke eugeniske skrækscenarier som helt usandsynlige og peger i stedet på de nye muligheder, som borgere har for at få viden om og indflydelse på eget helbred.

Ayo Wahlbergs og Nikolas Roses Governementaliseringen af livet: beregningen af den globale sundhed (kapitel 2.) viser, hvordan visse økonomisk-statistiske teknikker har skabt nye vidensobjekter, så som kvalitetsleveår, der ikke bare åbner op for nye måder for myndighederne at intervenere $\mathrm{i}$ folkesundhedens navn, men også giver borgerne muligheder for at opnå anerkendelse for eksistensen af levevilkårsproblemer, som de med større kraft kan forsøge at få håndteret.

Mitchell Deans Malthus-effekten: Befolkningen og den liberale styring af livet (kapitel 5.) er klart bogens mest originale, provokerende, men også noget problematiske analyse af nutidig sundhedspolitik. Deans originale og provokerende argument er, at Thomas Malthus tese og problematik fra midten af 1700 -tallet, at den hurtige befolkningsvækst vil underminere økonomisk og materiel vækst, stadig informerer aktuelle politiske interventioner rettet mod befolkningstilvækst og sundhed - især i ulandene, men også i en vis grad i de økonomisk udviklede samfund. Dean argumenterer, efter min mening ganske overbevisende, at liberal styring de seneste par århundrede ikke kun virker gennem den usynlige hånd, men også gennem en meget synlig og intervenerende hånd når det kommer til spørgsmålet om befolkningens vækst og kvalitet. Dean demonstrerer fint, hvordan klare Malthusianske problematikker artikuleres igen og igen i diverse befolknings- og sundhedsprogrammer. Imidlertid virker hans analyse flere steder lige lovlig ensidig og overser en række konkrete dynamikker og begivenheder, som har formet befolkningsproblematikkerne på ofte ganske forskellig vis. Dean er heldigvis selv opmærksom på dette problem og opfordrer andre til at gå yderligere i dybden at belyse de konkrete historiske udviklingstræk.

Endelig for det fjerde vil jeg fremhæve Niels Åkerstrøm Andersens og Justine Grønbæk Pors' Stilhedens kommunikation: hash-samtalen som potentialitetsteknologi (kapitel 7.). Kapitlet benytter Luhman's systemteori om kommunikation på en stringent og original facon til at spørge, hvordan det sociale system og - bliver det senere klart - offentlig intervention er muligt overfor unge, som ikke vil kommunikere om deres brug af hash. Kapitlet viser på den ene side, at denne magtteknologi er helt afhængig af den unges frivillige indsats: Kun hvis den unge vælger at snakke kan der begynde, at ske en bearbejdning af den unges selv. På den anden side er teknologien forberedt på, at den unge ikke vil svare og er designet til at blive ved indtil den unge begynder at åbne munden. Tavshed er ikke en option.

Flere af de andre kapitler er også ganske udmærkede. Men nu nærmer vi os bogens mindre heldige sider. Jeg var således ikke imponeret over Kathrine Hoffmann Piis (kapitel 6.) konklusion efter en i øvrigt glimrende analyse af patientcentreret forebyggelse, som konstaterer, at der er en risiko for at forbebyggelsesindsatsen bliver fragmenteret og usammenhængende (p. 234). Det virker også besynderligt, at en af de væsentligste pointer i Holger Højlunds og Anders la Cours analyse (kapitel 8.) af brugen af teknologier på plejehjemmene er en bekymring over, at de ældres psykiske og sociale behov ignoreres til fordel for snævre biologiske behov (p. 292). Konklusionerne i begge kapitler virker plausible og bekymringerne er helt legitime, men disse er ikke særligt originale og lyder mere 
som konklusioner fra en (god) konsulentrapport end fra en antologi, der kritisk vil belyse magt. Endelig er jeg heller ikke imponeret af Mads Peter Karlsens og Kaspar Villadsens analyse (kapitel 4.) af nyere informationskampagner, der benytter sig af ironisk distance og andre virkemidler, som tilsyneladende taler til vores usikre relation mellem irrationelt begær og rationelle overvejelser om den sunde livsførsel. I stedet for at analysere, hvordan adfærdspsykologien har spredt sin indflydelse ind i sundhedspolitikken og inspireret disse kampagner (herunder nudging), og dermed hvordan viden og magt spiller sammen, så får vi en temmelig forudsigelig psykoanalytisk moralsk opsang om, at vi samfundsforskere skal have mere øje for befolkningens libidinøse investeringer' (p. 174). Det er muligt, at psykoanalysen er bedre til at forstå befolkningens adfærd end adfærdspsykologien er - den er i hvert fald bedre til at producere esoteriske begreber - men jeg kan ikke se, hvordan den gør os klogere på magtudøvelse i sundhedspolitikken.

Bogens formål virker uforløst. Det anføres at bogen søger 'at præsentere dansk frontforskning og introducere aktuelle debatter i den internationale forskning til den danske kontekst' (p. 7). Det er svært at se, hvordan den første del af dette formål kan indfries uden en mere eller mindre systematisk oversigt over den eksisterende kritiske sundhedspolitisk forskning i Danmark. En sådan får vi ikke. Eksempelvis glimrer følgende ved deres fravær: Signild Vallgårdas historiske og komparative studier af nordisk sundhedspolitik, Nanna Nik-Meyers studier af indsatserne mod overvægtige, og Naja Vucinas PhD afhandling om de skiftende måder, hvorpå dansk sundhedspolitik har adresseret relationerne mellem sjæl og legeme. Den anden del af formålet, dvs. introduktion af aktuelle debatter i den internationale forskning til Danmark virker noget bedaget. De seneste snart to årtier har det været muligt for ansatte og studerende på de danske universiteter at downloade de seneste forskningspubli- kationer ved hjælp af nogle få klik på universitetsbibliotekernes databaser. Måske drejer det sig om, at det er svært at læse disse ting på engelsk? Næppe. Men hvad er så pointen? Den 13 sider korte indledning benyttes mere til at præsentere bogens kapitler end til at give et overblik over den internationale og kritiske sundhedspolitiske forskning. Den giver således ikke den nyankomne til feltet meget hjælp til at overskue dette.

Bogens struktur er heller ikke klar. Jeg savnede en eksplicitering af sammenhængen mellem de enkelte kapitler. Jo, kapitlerne kommer i større eller mindre grad ind på et eller flere af de i Indledningen nævnte hovedtemaer (ansvarliggørelse, økonomi, vidensformer og ledelsesteknologier), men en klar systematik skal læseren selv finde.

Endelig kniber det med at identificere antologiens målgruppe. På den ene side angives det at antologien 'især vil være relevant for professionelle og ledere indenfor dette felt' (p. 20), fordi den belyser eksemplariske magt- og ledelsesproblematikker. På den anden side fremføres det, at bogen 'henvender sig til studerende og fagfolk på sundheds- og samfundsvidenskabelige uddannelser' (omslag). Selvom disse to grupper i en vis grad kan være overlappende, så er der stor forskel på at skulle praktisere sundhedsledelse som en del af sit job på den ene side, og studere dette på behørig af feltet på den anden. Jeg kan se, at bogen kan have en relevans for samfundsvidenskabelige forskere og studerende, men jeg har svært ved at se hvordan sygeplejersker, læger og diverse ledere i sygehuse, regioner og kommuner skal kunne bruge bogen. Det skulle måske lige være de to kapitler forfattet af hhv. Pii og Højlund \& la Cour, (hhv. kapitel 6 og 8.).

Hvis målgruppen er danske forskere eller universitetsstuderende, som ikke allerede er inde i teorierne på feltet, så mangler der en oversigt over teorier, der kan benyttes til kritisk at belyse magtudøvelse i sundhedspolitik. Forfatterne har fat på flere: Foucault's magt-viden- 
analytik, Luhman's systemteori, Zizeks psykoanalytiske tilgang, samt Latours netværkssociologiske analytik. Selvom de fleste af disse har meget at byde på, så savner man en diskussion af deres ligheder og forskelle, styrker og begrænsninger, samt deres mulige samvirke, dvs. hvorvidt de med fordel kan søges bragt sammen i konkrete analyser. Der findes flere andre sociologiske og politisk-økonomiske tilgange, som kunne have været inddraget. Endelig er det besynderligt, at begrebet biopolitik, som indgår i antologiens undertitel og i fire ud af bogens ni kapitler, ikke søges defineret og diskuteret i det indledende kapitel. Selv blandt erfarne forskere indenfor området er der en væsentlig debat om, hvorvidt begrebet stadig er relevant og hvor bredt det skal forstås.

Kort sagt flere af bogens kapitler er yderst anbefalelsesværdige, det samme kan ikke siges om antologien som et samlet værk.

\section{Peter Triantafillou}

Roskilde Universitet 